UDK 528.932

\title{
COMPARATIVE ACCURACY ASSESSMENT OF GLOBAL DTM AND DTM GENERATED FROM SOVIET TOPOGRAPHIC MAPS FOR THE PURPOSES OF ROAD PLANNING
}

\author{
Taras HUTSUL ${ }^{1}$, Yaroslav SMIRNOV ${ }^{2}$ \\ Geodesy, Cartography and Territory Management Department, Faculty of Geography, \\ Yuriy Fedkovych Chernivtsi National University, Kotsyubynsky st. 2, 58012, Chernivtsi Ukraine

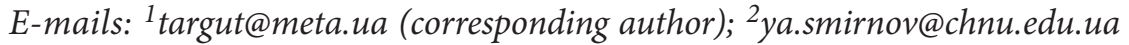

Received 25 October 2017; accepted 27 November 2017

\begin{abstract}
This article analyses the accuracy of global DTM comparatively to the Soviet topographic maps. The main aim of this study is to estimate the possibility of utilising global DTM for the purposes of road planning. In order to reach this aim, three separate territories with mountain, hill and plain topography were chosen. A DEM was generated for those territories from three different scale levels of Soviet topographic maps. The generated DEM rasters where then subtracted from SRTM and ASTER GDEM global DTMs. Results of the subtraction were analysed using statistical methods and verified with ground data. The Possibility of the replacement of DTMs generated from topographic maps by the global DTM data was proven for the different territories. The results obtained could be useful for the road engineers who still use Soviet topographic maps for the purposes of road planning. Also, some of the findings might be interesting for GIS-professionals who frequently use global DTMs.
\end{abstract}

Keywords: elevation, radar, SRTM, ASTER GDEM, contour line, geographic information system, topography, topographic map.

\section{Introduction}

Development of the methods of digital and mathematical modeling significantly changed technological processes of road construction. They are applied at all the steps of road construction, but especially valuable on the planning stage, when an engineer needs to find the perfect road location among multiple options. One of the best instruments to utilize is a Digital Terrain Model (DTM), these are widely used as a basis for the purposes of road planning. DTM's are a crucial part for finding of the best path for the road itself and locating of all the turns and crossings.

A DTM could be obtained by different ground and remote methods. Among them could be the aforementioned traditional topography surveys, GNSSmethods, methods of analog and digital photogrammetry, LIDAR-scanning, hydrolocation, radiolocation, satellite altimetry and interferometry. However, most of these methods are costly and that's the main reason why they are not very popular in the Post-Soviet states. Instead of these methods road planners and engineers are using Soviet topographic maps of different scale levels. Contours and elevation points are digitized from those maps and became source for the DTM creation.

The usage of Soviet topographic maps as source of the data for the DTM creation have a lot of disadvantages. The most serious of all, is that the Soviet maps were last time updated approximately 30 years ago and therefore are significantly outdated. The digitization of contours is also a very time consuming and tedious job with high probability of errors. Road planners do however in many Post-Soviet states (and especially in Ukraine) still prefer to use Soviet topographic maps because their accuracy meets the requirements of regulatory documents which are mandatory for usage by planning engineers.

Global elevation models, like ASTER GDEM or SRTM, on the other hand provide elevation data that are actual and convenient for the processing. Although these sources are rarely used by road planers at Post Soviet countries, because they considered as "imprecise" compared to the Soviet topographic maps. 


\section{Aim of the study}

To estimate the accuracy of global altitude data ASTER GDEM and SRTM comparatively to topographic maps of scale 1:25 000, 1:50 000 and 1:100 000 for various types of terrain (plain, hilly and mountain) at the territory of the Chernivtsi region (Fig. 1). Analyze the results of the comparison and estimate possibility of usage of this data for road planning.

The choice of the studied area is due to the characteristic's, uniqueness and peculiar contrast of the geomorphological structure (Herenchuk 1973). Parameters of the selected areas are shown on the
Figure 2 and this is territorially limited by trapezes of the corresponding map sheets.

\section{Previous research on the subject}

One of the first publications that reflects the possibility of quantitative remote estimation of terrain fluctuations on the surface of the earth contains the results of the application of the interferometric method to the radar data obtained from the aircraft board for the mapping purposes, this dates back to 1974. All the following publications, up to the 1980 s were also related to airborne radar data (Graham 1974).

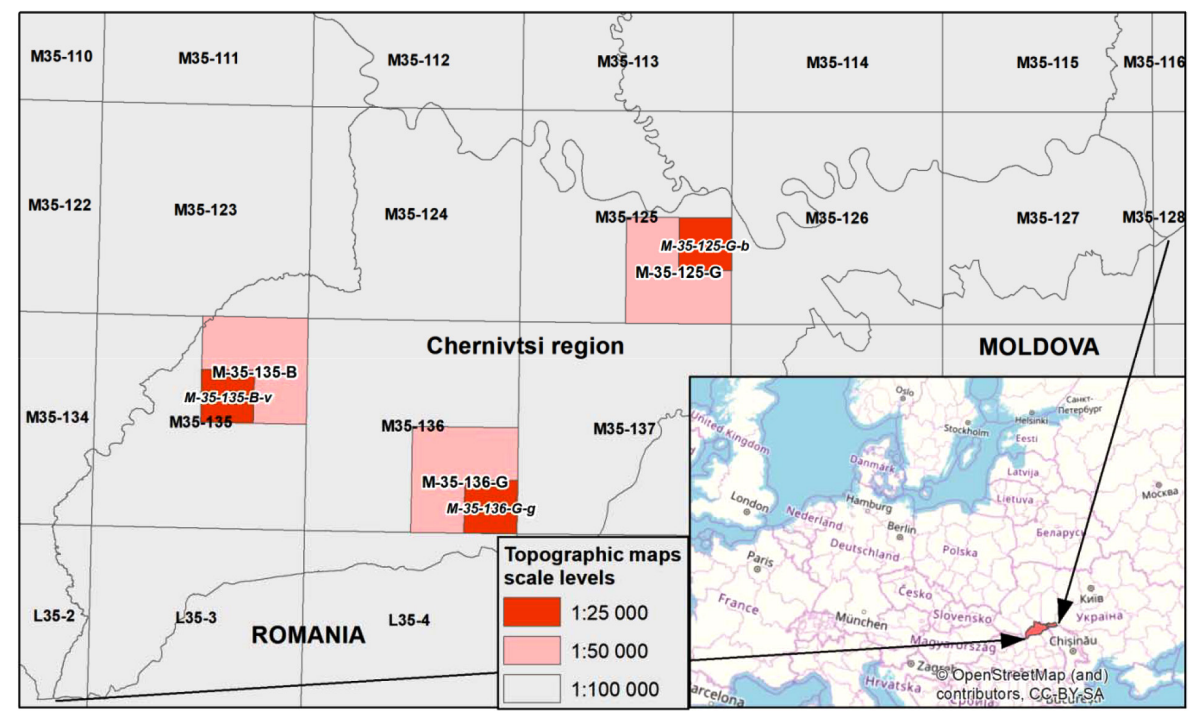

Fig. 1. The scheme of the investigated territory within the nomenclature sheets of topographic maps of different scales
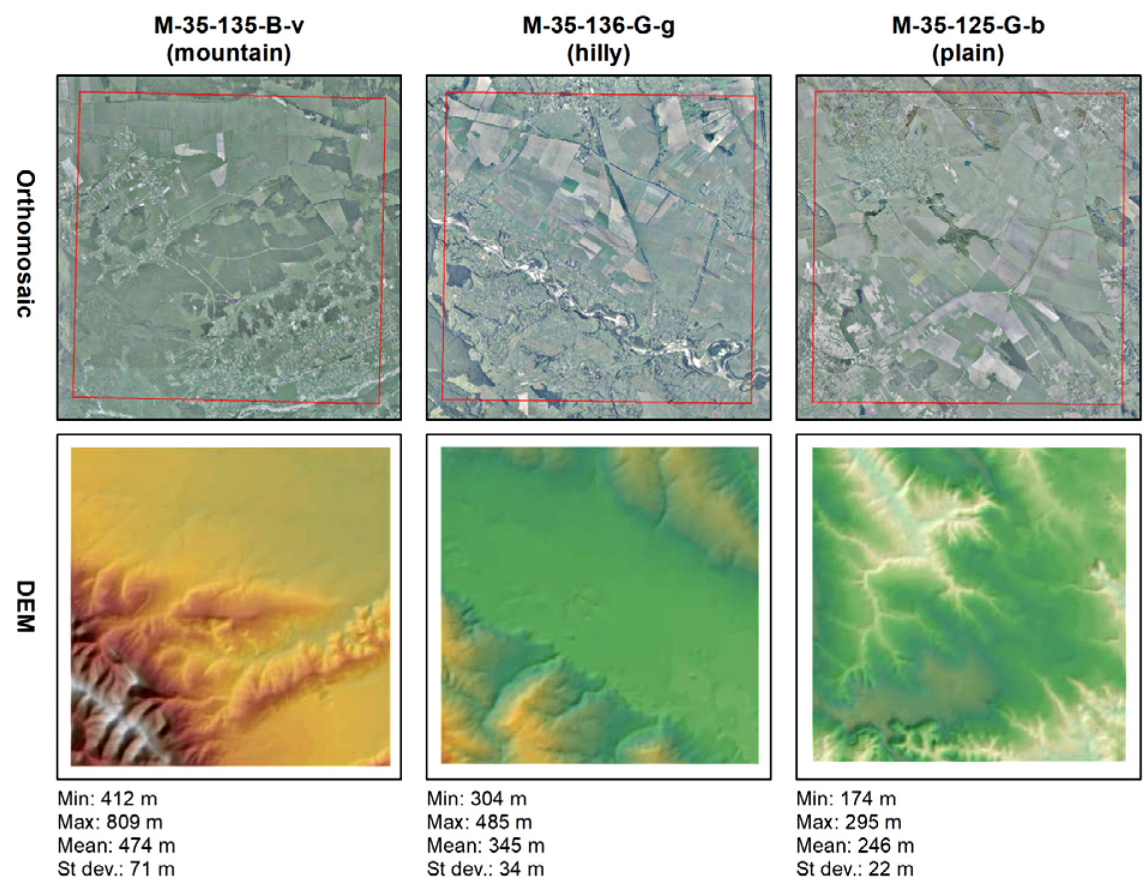

Fig. 2. Elevation characteristics of the researched polygons 
It was only in the late 1980s that the first publications with interferometric extractions made from the orbit were created for mapping purposes by constructing a map of heights from repeating orbits based on the data of the SIR-B radar (Zebker, Goldstein 1986).

The appearance in 1986 of the SPOT satellite with stereoscopic images allowed for data collection in relation to digital modeling of relief on large areas of the Earth's surface. Further satellites became equipped with various analog and digital sensors of the visible spectrum, these send spatial data to users for their further extraction and interpretation of three-dimensional information about the Earth surface (Nikolakopoulos et al. 2006).

1994 marked the emergence and application of radars SIR-C/X-SAR (a joint project of the USA, Germany and Italy). The number of publications on interferometric processing for specific instruments (SIRC/X-SAR, ERS-1/2, Tandem, JERS-1, SIR-C) increased between 1996 and 1997. At the same time, studies of the possibilities of interferometry for the registration of relief and displacements of the Earth's surface are considered with attention to the features of processing and correction of interferometric images (Zaharova 2011).

An ASTER mission took place, and stereoscopic images of a significant surface area between $83^{\circ}$ north latitude and $83^{\circ}$ south latitude were obtained at the end of 1999. Subsequent generation of DTM's with a resolution of $15 \mathrm{~m}$ in one pixel stimulated a new round of research.

In 2000 Yuriy Karpinsky and Anatoliy Lyashenko substantiated the use of the orographic-triangulation model. The ability to determine the height on it at any given point, corrected by the accuracy of the relief morphology provided a solution to a number of engineering problems, in particular the formation of elevation profiles (Karpinsjkyj, Ljashhenko 2000). In 2010, the Ukrainian Research Institute of Geodesy and Cartography formed a set of standards, which also contained regulatory requirements for the digital description of the relief.

The appearance in February 2000 of the SRTM data allowed new elevation data of the Earth surface between $60^{\circ}$ east longitude and up to $54^{\circ}$ south latitude to be obtained. Accordingly, in the future, there are also studies aimed at detecting the difference between the results of both shots (Forkuor, Maathius 2012). Currently SRTM data exists in several versions. The latest version today is version 4 dated on September 2014 (Nagornyuk 2015).
The accuracy of the SRTM matrix was studied by scientists from different countries. A. Karwel and I. Evoic estimate the error of SRTM matrix with the following values: for plain terrain $-2.9 \mathrm{~m}$, hilly $-5.4 \mathrm{~m}$ (Karwel, Ewiak 2008). In their view, the SRTM matrix meets the requirements for contour creation on topographic maps with a scale of 1:50 000 and smaller, and can also be used to create orthophotomaps based on high resolution satellite imagery.

Similar results have led to other researchers testing SRTM matrices for geographically dispersed objects, one of these was carried out by L. Muravyov, and it is possible to assert that the specified data can be applied for updating of topographic bases of territories, for which no other survey data exsits. Y. Karionov also applied various types of terrain (hilly - Sochi, mountain - Olkhon Island on Lake Baikal and plain - Saratov). From the materials of the comparative analysis, the author concluded that the accuracy of the SRTM matrix and the matrix of the topographic map is 1:100 000. The author suggests that the SRTM matrix, after additional correction, can also be used to create 1:25 000 scale orthophotomaps with areas of plain and hilly relief (Karionov 2010).

The question of the accuracy of SRTM and ASTER models for the territory of Ukraine was studied by A. Postelnyak (for the territory of Kyiv) (Posteljnjak 2013). He conducted an assessment of the quality of these models and notes that despite the relevance of research data for the rest of Ukraine, publications on the accuracy of such models is absent.

\section{Methodology}

For the first stage of research the SRTM and ASTER GDEM data was downloaded from the USGS Earth Explorer service. The research territory is covered by the two scenes of SRTM and ASTER data. Both datasets were stored in signed 16 bit GeoTIFF raster with WGS-84 coordinate system and EGM96 vertical datum. Using ArcGIS "Extract by Mask" tool and vector footprints of the chosen 1:25 000 scale topographic maps (lists: M-35-135-B-v, M-35-136-G-g, M-35-125-G-b) from each elevation raster was extracted part that was covered by the topographic maps. After the extraction obtained six separate rasters (three rasters for the SRTM and three rasters for ASTER GDEM). All these rasters were reprojected to Pulkovo 1942 Gauss Kruger zone 5 coordinate system (EPSG:28405) and resampled to the 25-meter resolution. This was done to ensure that all the raster's have 
the same extent, resolution and coordinate system and therefore could be compared with each other.

Soviet topographic maps were scanned from the paper sources, stored in the unsigned 8-bit JPEG raster's and georeferenced in Pulkovo 1942 Gauss Kruger zone 5 coordinate system. The overall number of the rasters was nine, lists: M-35-135 (scale 1:100 000), M-35-135-B (scale 1:50 000), M-35-135-B-v (scale 1:25 000) for the mountain area. Lists: M-35-136 (scale 1:100 000), M-35-136-G (scale 1:50 000), M-35-136-G-g (scale 1:25 000) for the hilly area and M-35-125 (scale 1:100 000), M-35-125-G (scale

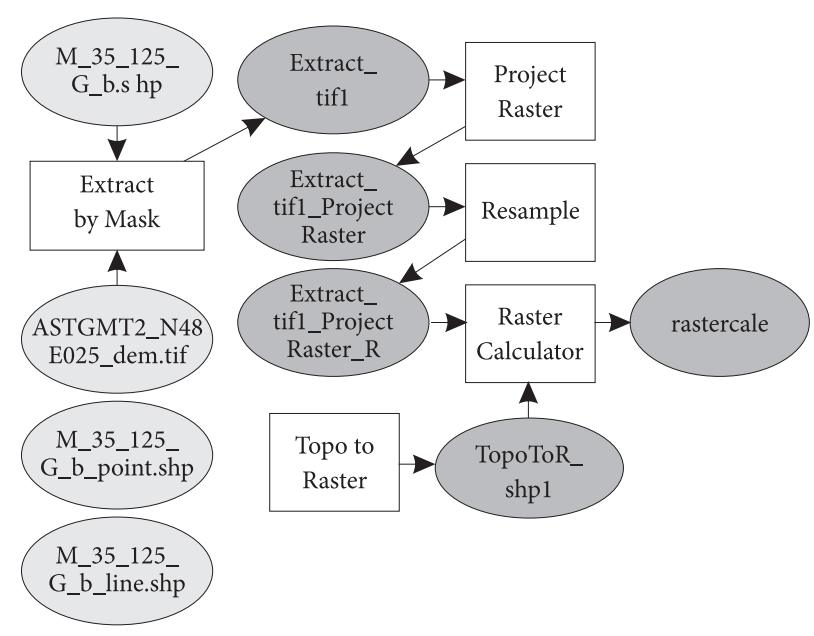

Fig. 3. ArcGIS geoprocessing model for the elevation difference raster generation
1:50 000), M-35-125-G-b (scale 1:25 000) for the plain area. Contours and elevation points were digitized for each of the map and stored in the separate shapefiles. Then, with ArcGIS “Topo to Raster” tool nine separate DTMs were generated. The resolution of each DTM was set to 25 meters to match the resolution of the SRTM and ASTER GDEM rasters. All the other parameters of the "Topo to Raster" tool were set accordingly to the general requirements of DTM generation.

To make a comparative analysis of the DTMs generated from the Soviet topographic maps and global DTMs a map algebra spatial analysis technique was utilized. Using the ArcGIS Raster Calculator tool, each of the rasters generated from the map was subtracted with rasters using SRTM and ASTER GDEM elevations. Also, the SRTM raster was subtracted from the ASTER GDEM raster. Therefore, the overall number of the rasters generated by this tool is equal to twentyone and each of them represents elevation difference. For instance, raster TOPO_ASTER_M_35_125_G_b. tif represents elevation difference between DEM generated from M-35-125-G-b topographic map (scale 1:25 000) and ASTER GDEM raster. On the Figure 3 presented geoprocessing model that was used for the generation of every elevation difference raster and on Figure 4 is a nine-elevation difference raster for the 1:25 000 scale. These were used as a basis for the further statistical analysis.
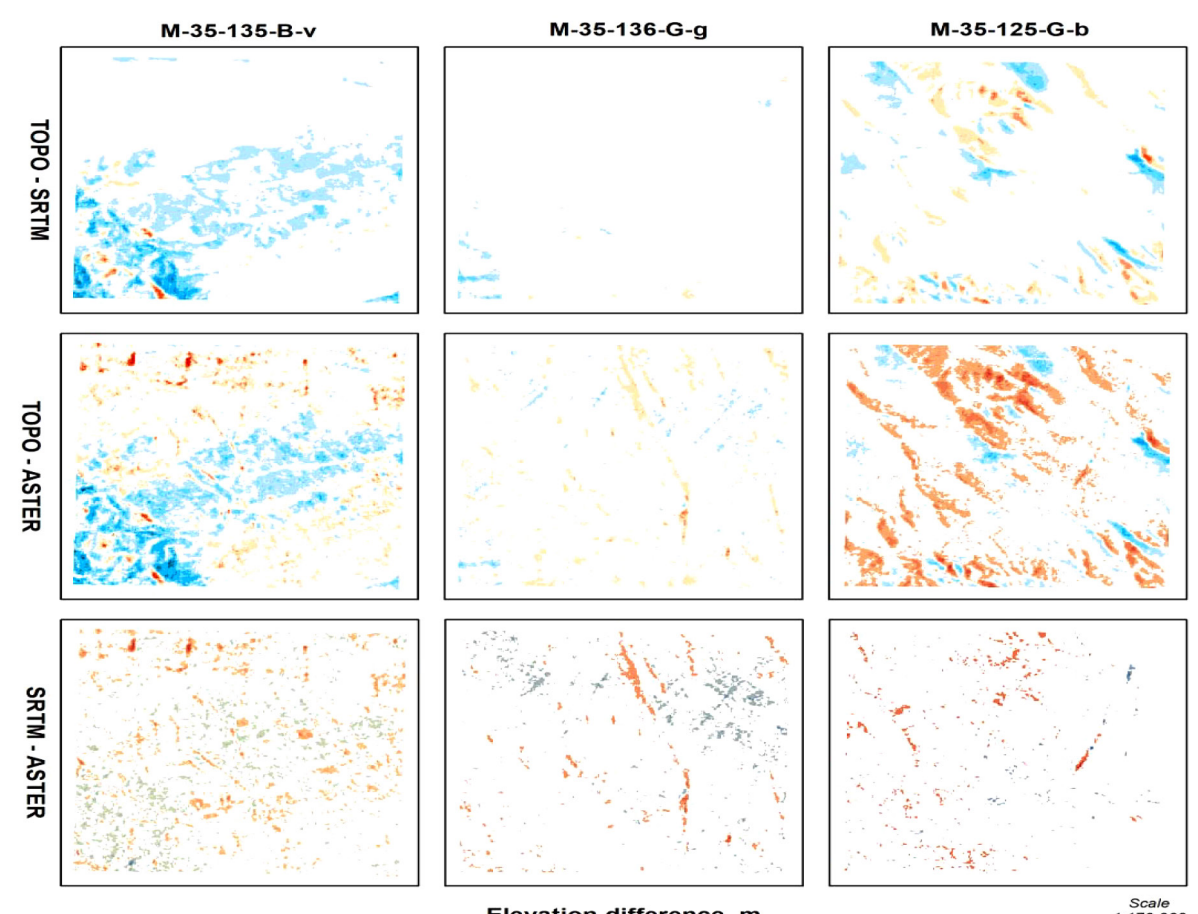

Elevation difference, $m$

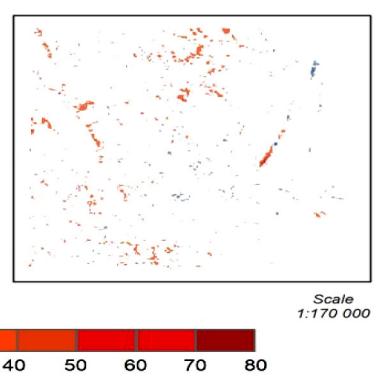

Fig. 4. The rasters of surface's difference according to different sources of DTM data 
I. Onkov suggests that it's possible to find the difference between the heights of the topographic surface and the SRTM model using two main approaches:

- Interpolation of the heights of the surface of the SRTM at specified points of the topographic surface with known reference marks of heights;

- interpolation of the heights of the topographic surface horizontally in the nodes of the matrix of SRTM heights (On'kov 2011).

For the calculation of statistical indicators in the above-mentioned study, the following equations have been used:

average:

$$
(\bar{d})=\frac{\sum d}{N},
$$

where $d$ - height difference of two matrices in a cell and $N$ - number of cells.

$$
d=H_{1}-H_{2},
$$

standard deviation:

$$
\sigma=\sqrt{\frac{\sum(d-\bar{d})^{2}}{N-1}},
$$

value that with probability will not exceed $90 \%$

$$
(\text { LE90 })=1.645 \times \sigma,
$$

value that with probability will not exceed $95 \%$

$$
(L E 95)=1.96 \times \sigma .
$$

Statistical processing of high-altitude matrices was performed in the environment of the Microsoft Office Excel 2013 table processor, this is shown in the Table 1.

The declared absolute accuracy of the global SRTM model is $16 \mathrm{~m}$ in height (Rodriguez et al. 2005). From the results obtained, it can be seen that the accuracy of the fourth version of SRTM data is at least twice as high. On the area enclosed by the map sheet M-35-125-G-b (plain territory), the proximity of the mean value and the mean-square deviation is observed, indicating a systematic error. If we consider the situation in the indicated area (see Fig. 2), then it can be noted that a large part is covered with shrub and woody vegetation, which greatly distorts the results in height. Studies (Korotin, Popov 2015) indicate the influence of tree heights on the deviation of DTM. Taking into account that no previous correction of DTM was carried out, the appearance of such values is obvious, but in the open areas of all researched territories standard deviations will be significantly smaller. Analyzing the mean square deviation in Table 1, the tendency of its direct dependence on the type of relief of the territory is revealed.

As in the previous case, a separate comparison of the ASTER GDEM and SRTM matrices among themselves (see Table 2), similarly revealed a systematic error in the plain area of the study, due to the presence of territories covered with shrub and bush vegetation.

The SRTM and ASTER GDEM elevation matrices can be analyzed more precisely by grouping the differences that, with a given probability of $90 \%$, these do not exceed the deviations of the characteristic point height estimate from its true height (see Table 3).

Since, in all cases with SRTM data (Fig. 5), such groups did not exceed the range from -15 to $+15 \mathrm{~m}$, it was decided to take them for a clear comparison for the construction of the two corresponding histograms.

ASTER GDEM data compared with SRTM showed slightly weaker results (Fig. 6). In the case of

\begin{tabular}{|c|c|c|c|c|c|c|c|c|c|c|c|c|c|c|c|c|c|c|}
\hline Scale & \multicolumn{6}{|c|}{$1: 25000$} & \multicolumn{6}{|c|}{$1: 50000$} & \multicolumn{6}{|c|}{$1: 100000$} \\
\hline Relief type & \multicolumn{2}{|c|}{ Plain } & \multicolumn{2}{|c|}{ Hilly } & \multicolumn{2}{|c|}{ Mountain } & \multicolumn{2}{|c|}{ Plain } & \multicolumn{2}{|c|}{ Hilly } & \multicolumn{2}{|c|}{ Mountain } & \multicolumn{2}{|c|}{ Plain } & \multicolumn{2}{|c|}{ Hilly } & \multicolumn{2}{|c|}{ Mountain } \\
\hline $\begin{array}{l}\text { Height } \\
\text { matrix }\end{array}$ & 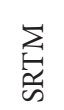 & 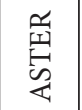 & 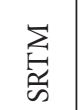 & 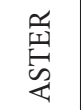 & 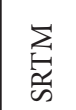 & 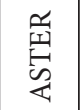 & 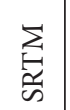 & 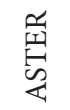 & 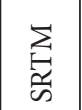 & 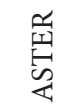 & 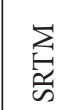 & 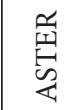 & 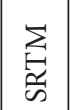 & $\begin{array}{l}\text { 舀 } \\
\text { 资 }\end{array}$ & 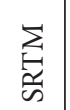 & 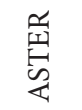 & 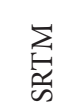 & 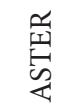 \\
\hline Average & 1.93 & 2.75 & 1.02 & 3.29 & -2.42 & -1.34 & 1.67 & 2.47 & 0.75 & 2.98 & -2.61 & -1.64 & 1.52 & 2.32 & 0.80 & 3.04 & -2.55 & -1.57 \\
\hline $\begin{array}{l}\text { Standard } \\
\text { deviation }\end{array}$ & 3.04 & 5.13 & 7.53 & 8.73 & 9.22 & 11.90 & 3.42 & 5.33 & 7.29 & 8.42 & 10.59 & 11.92 & 4.22 & 6.05 & 4.83 & 6.05 & 10.52 & 11.95 \\
\hline LE90, $\mathrm{m}$ & 5.00 & 8.43 & 12.39 & 14.37 & 15.17 & 19.57 & 5.63 & 8.76 & 11.99 & 13.85 & 17.42 & 19.60 & 6.94 & 9.95 & 7.95 & 9.96 & 17.31 & 19.65 \\
\hline LE95, $\mathrm{m}$ & 5.95 & 10.05 & 14.76 & 17.12 & 18.07 & 23.32 & 6.71 & 10.44 & 14.29 & 16.51 & 20.76 & 23.35 & 8.27 & 11.85 & 9.47 & 11.86 & 20.62 & 23.41 \\
\hline
\end{tabular}

Table 2. The statistical parameters of difference between height matrix ASTER and height matrix SRTM

\begin{tabular}{|l|c|c|c|}
\hline \multicolumn{1}{|c|}{ Relief type } & Plain & Hilly & Mountain \\
\hline $\begin{array}{l}\text { Nomenclature } \\
\text { sheet }\end{array}$ & $\begin{array}{c}\text { M-35-125- } \\
\text { G-b }\end{array}$ & $\begin{array}{c}\text { M-35-136- } \\
\text { G-g }\end{array}$ & $\begin{array}{c}\text { M-35-135- } \\
\text { B-v }\end{array}$ \\
\hline Average & 2.12 & 0.71 & 0.75 \\
\hline Standard deviation & 3.93 & 4.93 & 7.10 \\
\hline LE90, m & 6.47 & 8.11 & 11.68 \\
\hline LE95, m & 7.71 & 9.66 & 13.92 \\
\hline
\end{tabular}

Table 1. The statistical parameters of map's height difference DTM by topographical maps and matrix data SRTM and ASTER 
Table 3. Ranges of deviations of high-grade DTM markings satisfying the condition LE90 for different scale and conditions of relief

\begin{tabular}{|c|c|c|c|c|c|c|}
\hline Scale & \multicolumn{2}{|c|}{$1: 25000$} & \multicolumn{2}{|c|}{ 1:50 000} & \multicolumn{2}{|c|}{$1: 100000$} \\
\hline Relief type & SRTM & ASTER_GDEM & SRTM & ASTER_GDEM & SRTM & ASTER_GDEM \\
\hline Plain & {$[-5,+5]$} & {$[-9,+9]$} & {$[-6,+6]$} & {$[-9,+9]$} & {$[-7,+7]$} & {$[-10,+10]$} \\
\hline Hilly & {$[-12,+12]$} & {$[-15,+15]$} & {$[-11,+11]$} & {$[-15,+15]$} & {$[-8,+8]$} & {$[-11,+11]$} \\
\hline Mountain & {$[-14,+14]$} & {$[-24,+24]$} & {$[-14,+14]$} & {$[-19,+19]$} & {$[-14,+14]$} & {$[-20,+20]$} \\
\hline
\end{tabular}

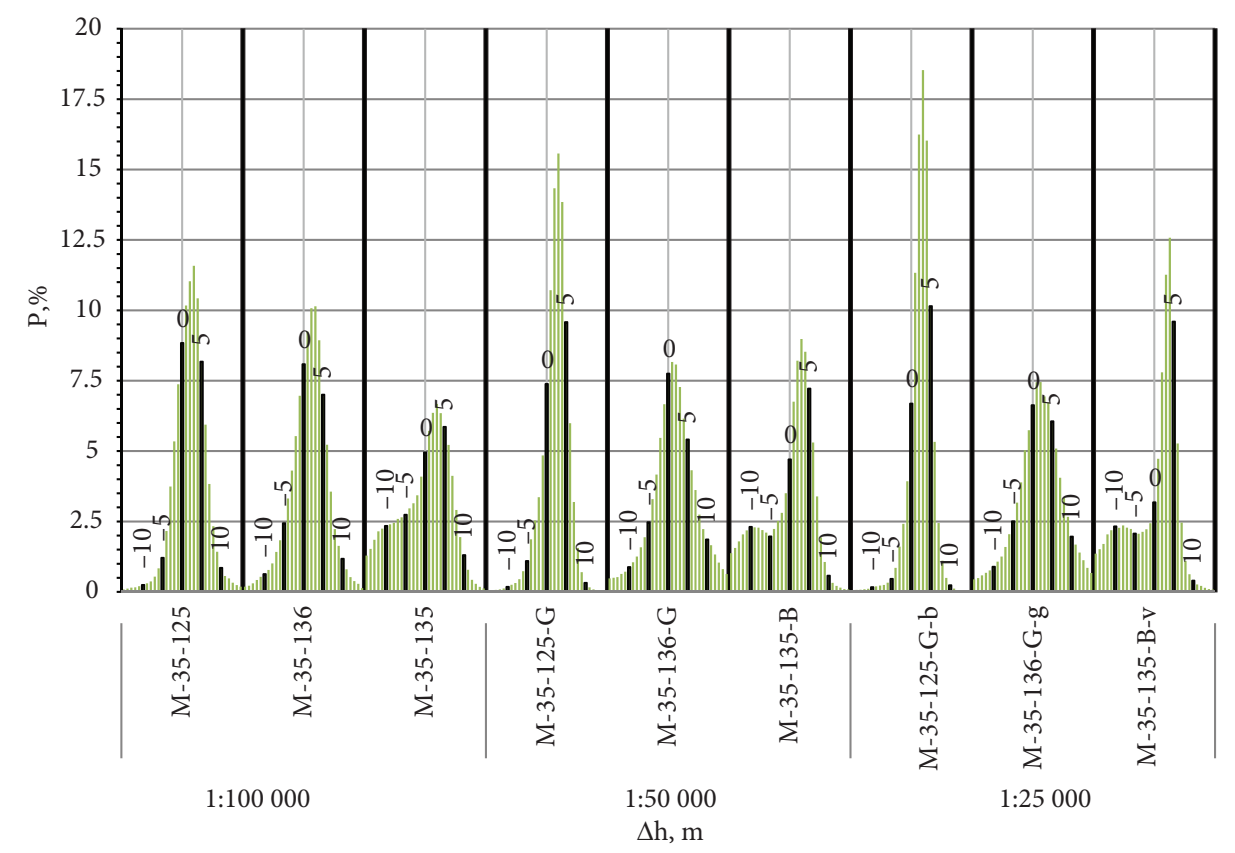

Fig. 5. SRTM Elevation Error Distribution Histogram for different scales and terrain conditions

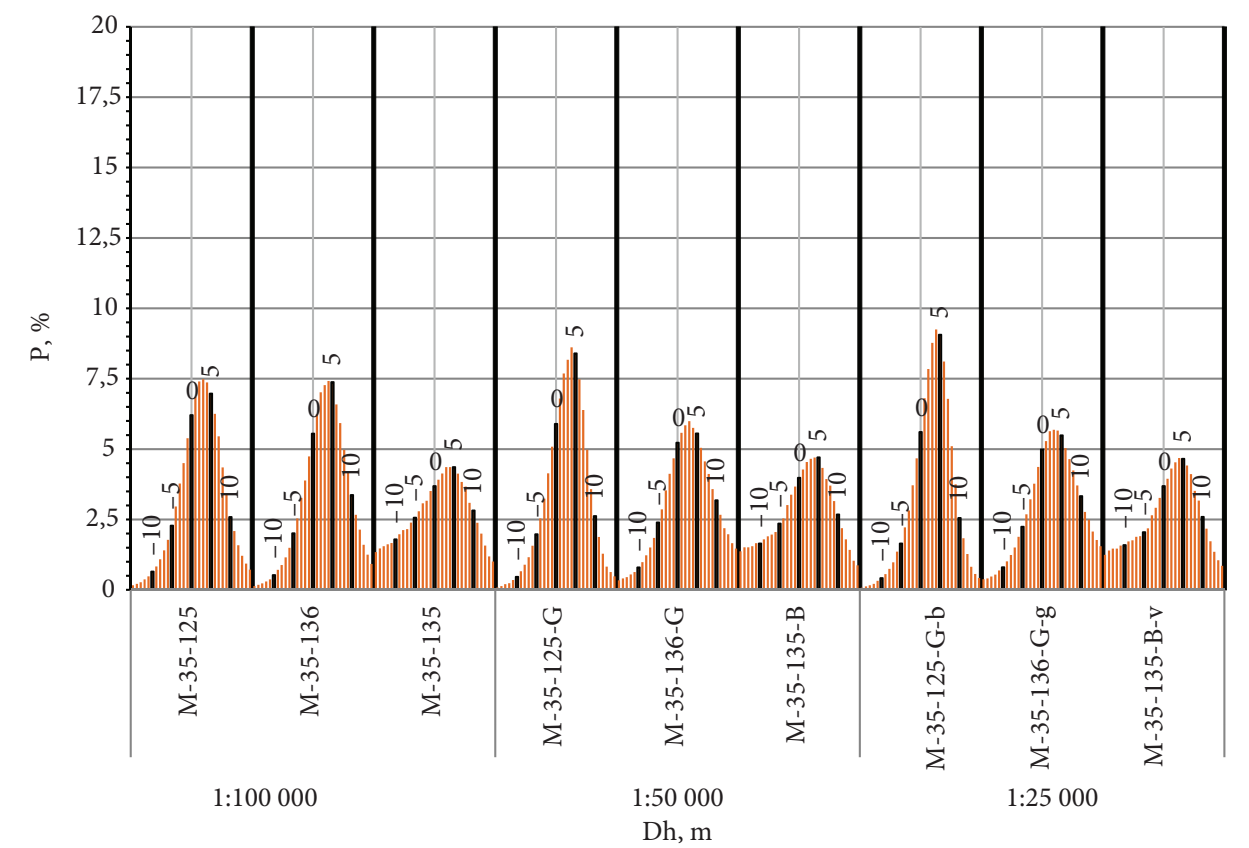

Fig. 6. ASTER GDEM Elevation Error Distribution Histogram for different scales and terrain conditions 
the mountain areas, for a scale of 1:100 000 it took an interval of -20 to $+20 \mathrm{~m} ; 1: 50000-$ from -19 to $+19 \mathrm{~m}$ and 1:25 000 from -24 to $+24 \mathrm{~m}$.

Given that the vertical scales at Figures 5 and 6 are identical, it is visually noticeable that, in the case of SRTM, a much larger fraction of data in practically all cases is characterized by a smaller difference and being in close proximity to the reference values. However, in both cases there is a clear tendency: on a plain type of terrain, a greater number of values are characterized by smaller standard deviations in relation to reference heights, and vice versa, with the transition to a more complex topography, the trend is reversed.

Interesting patterns are also found during the analysis of linear correlation matrices (Table 4).

Table 4 shows the existence of a very high level relationship between topographic data derived from topographic maps and global DEMs for the research area. Generalization of elevation data on the topographic maps leads to a growth of the correlation with global DEMs. Thus, in the medium-scale maps, the index grows to almost complete interconnection. In all cases, correlation of the SRTM data and DEMs derived from topographic maps are stronger than the correlation between the same maps and ASTER DEM data.

The correlation analysis of the difference models of global models (see Table 5) shows a practically complete interconnection in a plain area for scales of 1:100 000 and 1:50 000, and a strong level of correlation for a scale of 1:25 000. Instead, the level of correlation in the hilly area is weak and increases to an average with an increasing scale. The Mountain area is characterized by a uniform high level of correlation between raster surfaces regardless of the scale of the model being created.

The quality of DTM can be estimated by comparing the results obtained with the normative values of the mean square deviation of the definition of the height position of the point. According to basic guidelines for the creation of the topographic maps on the territory of Ukraine (Geoguide 1999), at each maps sheet of the 1:25 000 scale must be at least three points of the horizontal and vertical geodetic basis, including the points of the state geodetic network, geodetic networks of congestion and points of sampling networks fixed on the ground by the centers.

However, it should be considered that the height of the nodes of the regular network that are determined relatively to the surface of the geoid EGM96, which is rounded to one meter and represented by integers in the length of 2 bytes (Meshin 2012).

Control points were selected exclusively on the open, vegetation free territories (Table 6). The obtained results showed significantly less error in the

Table 4. The correlation matrix of raster surfaces

\begin{tabular}{|l|c|c|c|c|c|c|}
\hline \multicolumn{1}{|c|}{ Scale } & \multicolumn{2}{c|}{$1: 25000$} & \multicolumn{2}{c|}{$1: 50000$} & \multicolumn{2}{c|}{$1: 100000$} \\
\hline Height matrix & SRTM & ASTER_GDEM & SRTM & ASTER_GDEM & SRTM & ASTER_GDEM \\
\hline Plain & 0.937 & 0.921 & 0.939 & 0.923 & 0.968 & 0.956 \\
\hline Hilly & 0.970 & 0.962 & 0.969 & 0.962 & 0.968 & 0.960 \\
\hline Mountain & 0.966 & 0.962 & 0.966 & 0.962 & 0.965 & 0.962 \\
\hline
\end{tabular}

Table 5. The correlation matrix of raster difference surfaces by different sources of DTM data

\begin{tabular}{|c|c|c|c|c|c|c|c|c|c|c|c|c|c|}
\hline \multicolumn{2}{|c|}{ Relief type } & \multicolumn{4}{|c|}{ Plain } & \multicolumn{4}{|c|}{ Hilly } & \multicolumn{4}{|c|}{ Mountain } \\
\hline \multirow{2}{*}{\multicolumn{2}{|c|}{$\begin{array}{c}\text { Height matrix } \\
\text { ASTER }\end{array}$}} & \multicolumn{4}{|c|}{ SRTM } & \multicolumn{4}{|c|}{ SRTM } & \multicolumn{4}{|c|}{ SRTM } \\
\hline & & 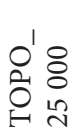 & 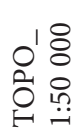 & 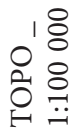 & $\begin{array}{l}\frac{1}{4} \\
\text { 点 } \\
2\end{array}$ & 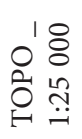 & \begin{tabular}{l}
18 \\
0 \\
0 \\
$\circ$ \\
0 \\
0 \\
\hdashline \\
$H$
\end{tabular} & 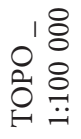 & 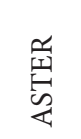 & 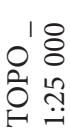 & 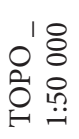 & 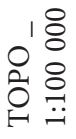 & \\
\hline \multirow{4}{*}{ 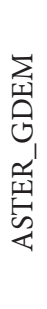 } & SRTM & & -0.08 & 0.03 & 0.50 & & -0.26 & -0.25 & -0.15 & & 0.04 & 0.03 & 0.04 \\
\hline & $\begin{array}{l}\mathrm{TOPO}_{-} \\
1: 25000\end{array}$ & 0.61 & 0.75 & 0.37 & 0.61 & 0.83 & 0.31 & 0.23 & 0.18 & 0.61 & 0.77 & 0.76 & 0.70 \\
\hline & $\begin{array}{l}\text { TOPO_ } \\
1: 50000\end{array}$ & 0.02 & 0.42 & 0.98 & 0.85 & 0.78 & 0.28 & 0.41 & 0.24 & 0.63 & 0.78 & 0.79 & 0.73 \\
\hline & $\begin{array}{c}\mathrm{TOPO}_{-} \\
1: 100000\end{array}$ & 0.48 & 0.32 & 0.87 & 0.98 & 0.72 & 0.18 & 0.21 & 0.57 & 0.64 & 0.72 & 0.73 & 0.79 \\
\hline
\end{tabular}


Table 6. Difference of high values of global surfaces with respect to separate markings of topographic maps

\begin{tabular}{|c|c|c|c|c|c|c|}
\hline $\begin{array}{l}\text { Relief } \\
\text { type }\end{array}$ & $\begin{array}{c}\text { The name of the point } \\
\text { State Geodetic Network or } \\
\text { altitude mark }\end{array}$ & $\begin{array}{l}\text { Height on } \\
\text { topographic map, } \\
\text { m }\end{array}$ & $\begin{array}{l}\text { Height on matrix } \\
\text { ASTER_GDEM, } \\
\text { m }\end{array}$ & $\begin{array}{l}\text { Difference, } \\
\mathrm{m}\end{array}$ & $\begin{array}{l}\text { Height on } \\
\text { matrix SRTM, } \\
\text { m }\end{array}$ & $\begin{array}{c}\text { Difference, } \\
\mathrm{m}\end{array}$ \\
\hline \multirow{3}{*}{ Plain } & Anadoly & 252,812 & 246 & 6,812 & 246 & 6,812 \\
\hline & Doly'nyany & 293,942 & 282 & 11,942 & 290 & 3,942 \\
\hline & Vlady'chna & 294,678 & 293 & 1,678 & 286 & 8,678 \\
\hline \multirow{3}{*}{ Hilly } & Slobidka & 404,505 & 398 & 6,505 & 395 & 9,505 \\
\hline & water edge " 320,6 " & 320,600 & 316 & 4,600 & 319 & 1,600 \\
\hline & water edge " 312,5 " & 312,500 & 301 & 11,500 & 310 & 2,500 \\
\hline \multirow{3}{*}{ Mountain } & Chereshen'ka & 439,645 & 429 & 10,645 & 434 & 5,645 \\
\hline & Sy'sna & 418,352 & 407 & 11,352 & 413 & 5,352 \\
\hline & Kichera & 785,400 & 774 & 11,400 & 774 & 11,400 \\
\hline
\end{tabular}

SRTM matrix compared to the ASTER GDEM matrix in almost all the cases. The emergence of maximum differences has quite objective reasons. It should be considered that the location of "Vladichna" and "Slobidka" control points on the corresponding sheets of topographic maps is near the contours with a minimum distance, which means the slope values are greater. Thus, we can assume that a slight linear displacement in any of the directions would give a completely different result. In this case, everything is limited to raster resolution capabilities.

\section{Results}

One of the features of the Ukrainian hypsometric school is that when representing the contours on the topographic maps, much attention is paid not only to their correct metric representation, but also to the geographic plausibility, accuracy of the image, and the plasticity of contour appearance. Similar requirements for the image and the relief are also given in the regulatory documents.

The use of statistical estimation methods is justified, but with greater probability it is possible to establish the accuracy of the created model and its level of correlation with the real nature of the study area relief. Instead, comparing the results of a model to individual points can lead to a probable fall in the point of anomalies, which exceeds the value LE90.

Of all the constructed difference maps, the least standard deviation and coefficient of variation is specific for the DTM SRTM of plain $(4.83 \mathrm{~m})$ and hilly $(3.04 \mathrm{~m})$ terrain, which indicates that these DTMs are as close as possible to topographic maps of scale 1:25 000. This is indicated by the histogram of the distribution of heights of the DTM (Fig. 4).
The results for ASTER GDEM for the same area and scale had standard deviations larger (for the flat $6.05 \mathrm{~m}$ and the hilly $-5.12 \mathrm{~m}$ ). In addition, in all the cases, correlation analysis showed a lower relationship of ASTER GDEM with DEMs constructed from the topographic maps elevation data.

In special studies, it is noted that in some cases (in particular, in flat and hilly areas), data is more accurate (Karionov 2010), while in mountains - accuracy is lesser, and the presence of systematic errors caused by averaging heights in the area of the radar spot. Moreover, the heights of the peaks are always low, and the bottom of the narrow canyons is overestimated. These features require additional measurements in each case in the reference section (Murav'ev 2008). Thus, the dependence of DTM on the terrain roughness and the type of the area land use and land cover is important.

\section{Conclusions}

Obtained results allow the following conclusions to be drawn.

1. SRTM data, with proper correction and analysis, fall within the acceptable accuracy range for the purposes of road planning.

2. The use of open radar interfacing data allows achieving a tangible economic effect. DTMs built on their basis can be used in surveys at the stage of feasibility study, for tracing the passage of linear structures, etc.

\section{Discussion}

Despite general suitability of global elevation models for the purposes of road planning, it's important to keep in mind that these sources of elevation data have their limitations. First of all, SRTM data contains 
not actual topographic elevations, but surface heights and therefore should be corrected, especially for the regions with forest cover or many buildings. But even with the correction, the accuracy of the global elevation models is not enough for the construction process. And a few years ago, the only way to obtain high resolution elevation data was to perform field topographic surveys, nowadays such a data could be collected with LIDAR. These instruments are still rarely being used in Ukraine and other post-Soviet countries. But considering the experience of other European countries, they would become more commonly used. And, considering much bigger areas that could cover LIDAR survey comparatively to the topographic, it's obvious that they would be used not only during road construction but also at the planning stage. But before that time, global elevation models could be the only reasonable alternative to the topographic maps, for the road planning purposes.

\section{References}

Forkuor, G.; Maathius, B. 2012. Comparison of SRTM and ASTER derived digital elevation models over two regions in Ghana - implications for hydrological and environmental modeling, studies on environmental and applied geomorphology, in T. Piacentini (Ed.). Studies on environmental and applied geomorphology. InTech, 219-240. https://doi.org/10.5772/28951

Geoguide. 1999. Osnovni polozhennja stvorennja ta onovlennja topoghrafichnykh kart masshtabiv 1:10000, 1:25000, 1:50000, 1:100000, 1:200000, 1:500000, 1:1000000 [online], [cited 17 October 2017]. Available from Internet: http://www.geoguide.com.ua/basisdoc/basisdoc.php?part=tgo\&art=3201

Graham, L. 1974. Synthetic interferometer radar for topographic mapping, Proceedings of the IEEE 62(6): 763-768. https://doi.org/10.1109/PROC.1974.9516

Herenchuk, K. 1973. Pryroda Chernivetskoi oblasti. Lviv: Vyscha shk.

Karionov, Y. 2010. Ocenka tochnosti matricy vysot SRTM, Geoprofi (1): 48-51.

Karpinsjkyj, J.; Ljashhenko, A. 2000. Oroghrafichno-trianghuljacijna cyfrova modelj reljjefu, Visnyk gheodeziji ta kartoghrafiji 3(18): 28-33 (in Ukrainian).

Karwel, A.; Ewiak, I. 2008. Estimation of the accuracy of the SRTM terrain model on the area of Poland, in The International Archives of the Photogrammetry, Remote Sensing and Spatial Information Sciences 37(B7): 169-172.

Korotin, A.; Popov, E. 2015. Ocenka tochnosti cifrovyh modelej rel'efa, primenyaemyh dlya territorial'nyh issledovanij, in Yubilejnaya 25-a Mezhdunarodnaya konferenciya (GraphiCon2015), 22-25 September 2015, Protvino, Russia [online], [cited 17 October 2017]. Available from Internet: http:// www.graphicon.ru/html/2015/papers/21.pdf

Meshin, I. 2012. Postroeniya cifrovoj modeli rel'efa po dannym radarnoj interferometricheskoj s'emki, Territoriya CREDO 1(44) [online], [cited 17 October 2017]. Available from Internet: http://www.credo-dialogue.com/ getattachment/9949ae88-b4df-4b8f-9936-232be381d1a7/ Postroeniya-cifrovoi-modeli-rel'efa-po-dannym-radar.aspx

Murav'ev, L. 2008. Vysotnye dannye SRTM protiv topografi-cheskoj s'emki [online], [cited 17 October 2017]. Available from Internet: http://web.ru/db/msg.htmlmid=1177761

Nagornyuk, K. 2015. Cifrovaya model' rel'efa SRTM uluchshena do $31 \mathrm{~m}$ s ranee dostupnyh 90 metrov, oficial'nyj blog ArcGIS [online], [cited 17 October 2017]. Available from Internet: http://esri-cis.ru/blogs/?page=post\&blog=arcgis\&po st_id=SRTM (in Russian)

Nikolakopoulos, K.; Kamaratakis, E.; Chrysoulakis, N. 2006. SRTM vs ASTER elevation products. Comparison for two regions in Crete, Greece, International Journal of Remote Sensing 27(21): 4819-4838. https://doi.org/10.1080/01431160600835853

On'kov, I. 2011. Ocenka tochnosti vysot SRTM dlya celej ortotransformirovaniya kosmicheskih snimkov vysokogo razresheniya, Geomatika v(3): 40-46.

Posteljnjak, A. 2013. Ocinjuvannja tochnosti vysot cyfrovykh modelej reljjefu SRTM ta ASTER GDM, Visnyk gheodeziji ta kartoghrafiji (4): 17-21.

Rodriguez, E.; Morris, C.; Belz, J., et al. 2005. An assessment of the SRTM topographic product. Jet Propulsion Laboratory, Pasadena, California.

Zaharova, L. 2011. Metody radiolokacionnoj interferometrii $v$ issledovanii harakteristik zemnyh pokrovov: $\mathrm{PhD}$ thesis. Fryazino.

Zebker, H.; Goldstein, R. M. 1986. Topographic mapping from interferometric synthetic aperture radar observations, Journal of Geophysical Research 91(B5): 4993-4999.

Zebker, H.; Goldstein, R. 1987. Interferometric radar measurement of ocean surface current, Nature 328(20): 707-709.

Taras HUTSUL. Born at February 8, 1990 in Chernivtsi, Ukraine. Obtained master degree in surveying and cadaster in 2011 at Chernivtsi national university. Starting from 2011 working at Chernivtsi national university as a lecturer. Beginning from 2013 is working on his PhD thesis at Kyiv National University of Construction and Architecture. Main scientific interests: road planning and construction, surveying, terrain modeling.

Yaroslav SMIRNOV. Born at August 12, 1989 in Chernivtsi, Ukraine. Obtained master degree in surveying and cadaster in 2010 at Chernivtsi national university and at the same year started to work there at the lecturer position. In 2015 obtained PhD degree in cartography at Taras Shevchenko National University of Kyiv. Main scientific interests include: GIS-analysis, cartographic design and thematic mapping. 